\section{Designing and Application of $\beta$-Cyclodextrin-based Copolymers for Remediation of Azo Dyes}

FATIMA TARIQ - Department of Environmental Sciences, Fatima Jinnah Women University - Fatimatariq86@gmail.com

UZAIRA RAFIQUE - Department of Environmental Sciences, Fatima Jinnah Women University Érkezett: 2018. 01. 13. - Received: 13. 01. 2018. - https://doi.org/10.14382/epitoanyag-jsbcm.2018.15

\begin{abstract}
The world is facing pollution challenges globally and there is need to implement clean and costeffective technologies to remediate the environment. The plan of present research work is to copolymerize synthetic materials ( $\beta$-Cyclodextrin) as cost effective and eco-friendly adsorbents for environmental remediation. The synthetic material is copolymerized and further modified with beetroot peels. The samples were investigated under FTIR and SEM. The frequencies were recorded at $2931 \mathrm{~cm}^{-1}$ and $1016 \mathrm{~cm}^{-1}$ confirm the presence of $\beta$-Cyclodextrin in the synthesized copolymer. The wider cavities depicted under SEM are expected to enhance the uptake capacity of modified copolymers for organic moieties. The inclusion complex of $\beta$-Cyclodextrin depicts rectangular features with milky white surface confirmed by XRD. The synthesized copolymer was applied as adsorbent in a batch mode to determine efficiency for the amputation of a wide range of environmental pollutants. The results of UV-Vis have proved that Crystal violet and Congo red show (87\%) and (69\%) removal, respectively at optimum dose. The study concludes the successful synthesis of $\beta$-Cyclodextrin modified with beetroot peels as efficient adsorbent for the removal of dyes.
\end{abstract}

Keywords: $\beta$-Cyclodextrin, Crystal violet (CV), Congo red (CR), SEM, FTIR
Fatima TARIQ Ph.D. Ph.D scholar from Fatima Jinnah Women University, has completed her Ph.D. in 2018 with dissertation entitled "Development of hybrids as nanocarriers for targeted drug delivery". She also carried out applications of computational modelling on synthesized hybrids from University College London, UK. She has number of publications from her M.Phil and Ph.D research work. In addition she has file a patent along with the co-author of chapter based on various cinematographic techniques in manual.

Uzaira RAFIQUE

Dean of Faculty of Sciences and Technology at Fatima Jinnah Women University, Rawalpindi Pakistan. Her research expertise based on synthesis, structure and physical properties

of inorganic, organic, hybrid and composite materials. The basic aim of her research group is to discover new materials with potential usefu properties particularly with projected applications in field of environmental remediation.

\section{Introduction}

Rapid economic development due to increased industrial activities is a great challenge for the global world. The reason is lack of economical and eco-friendly remediation technologies for environment. Among variety of physio-chemical processes, adsorption technique [5] marks its distinction due to the communal mechanism for the removal of organic and inorganic pollutants from the environment. Mostly organic pollutants are of great concern due to their toxicity, persistence and bioaccumulation in living organisms [20]. It is alleged that eco-balance is disturbed due to the disposal and discharge of toxic and noxious pollutants by industries such as textile, leather, food and paint [12]. It is proposed that extensive applications of azo dyes in food, tanning, paper and textile at elevated level dissuade the attention of researchers towards the control of dyes by designing structures or materials from both eco-friendly and economical sources [13]. It is known that synthesis of adsorbents from natural [4] and synthetic sources can be employed as inexpensive approach but it defines certain limitations when they are used as adsorbent for environmental processes [11]. Present study was conducted to reduce the azodyes burden from environment by synthesizing $\beta$-Cyclodextrin based copolymers [8]. This new product exhibit exclusive properties such as high adsorption capacities due to the formation of inclusion complexes through host guest interactions. These interactions are responsible for the removal of toxic inorganic and organic moieties even at trace level [23].

\section{Materials and methods}

The materials $\beta$-Cyclodextrin, pyridine and ethanol were the reagents used for synthesis and purchased commercially from Sigma Aldrich. Apparatus included a UV-Vis spectrophotometer (SCHIMADU-1403).

\subsection{Synthesis of $\beta$-Cyclodextrin based copolymer}

The present protocol is based on synthesis of copolymers from waste sources to use as efficient adsorbents for the removal of environmental pollutants (azo dyes). In the preliminary tread, $\beta$-Cyclodextrin (60 mg) [22] was dissolved in $75 \mathrm{ml}$ of pyridine and heated at $70^{\circ} \mathrm{C}$. Beetroot peels $(28 \mathrm{mg})$ and acetic acid $(25 \mathrm{ml})$ were added and stirred in above mixture. Brown yellow solid crystals formed after 30 minutes. The mixture was washed successively with distilled water and ethanol. The beetroot modified $\beta$-Cyclodextrin based synthesized copolymer is coded as CCD. Modification of copolymer with beetroot peels is reported for the first time in the present research. Direct co-condensation approach is adopted for the synthesis of copolymers, as this process is easier, convenient and efficient [7]. The objective of modification is to enhance the removal efficiency of synthesized co-polymer [9]. The copolymer before and after modification with beetroot peels is subjected to different characterization techniques.

\section{Characterization}

The synthesized material is subjected to following characterization techniques such as FTIR (Fourier Transform 
Infrared (FTIR-8400 Schimadzu, Japan) spectrophotometer, XRD (STOE) and SEM (JEOL tsm-6490, Japan).

\subsection{FTIR}

The recorded FTIR spectrum of $\beta$-Cyclodextrin Copolymer is shown in Fig. 1. The peaks at $2932-3364 \mathrm{~cm}^{-1}$ identify the presence of $\mathrm{N}-\mathrm{H}$ and $\mathrm{O}-\mathrm{H}$ stretching in raw beetroot (also observed by [3] while peaks characteristics of $\beta$-Cyclodextrin are observed at $1033 \mathrm{~cm}^{-1}$ and $1357 \mathrm{~cm}^{-1}$ ). The peaks are assigned to anti-symmetric stretching of $\mathrm{C}-\mathrm{O}-\mathrm{C}$ and vibrational stretching of $-\mathrm{C}=\mathrm{C}-$, duly supported by [10]. The modification of $\beta$-Cyclodextrin with beetroot peels resulting in modified copolymer is confirmed by the peak observed at $1697 \mathrm{~cm}^{-1}$. In addition, the peak at $2960.83 \mathrm{~cm}^{-1}$ [28] indicates the presence of Hydrogen free - $\mathrm{NH}-\mathrm{COO}-,-\mathrm{NH}_{2}-$ and $-\mathrm{COOH}$ groups in the modified co-polymer.

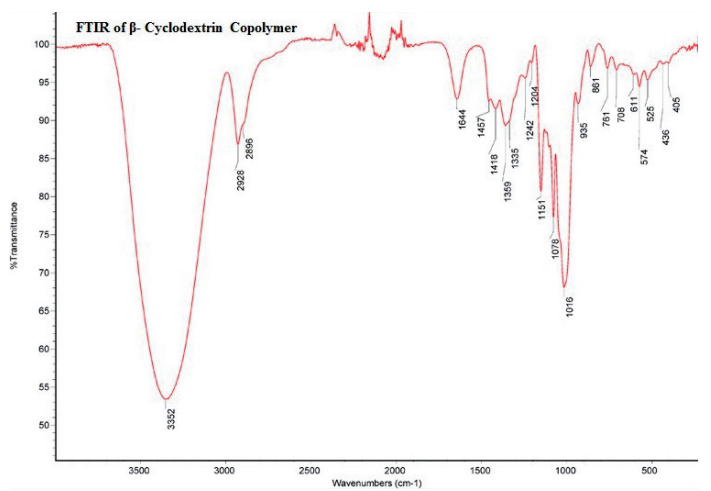

Fig. 1. FTIR spectrum of $\beta$-Cyclodextrin Copolymer

1. ábra $\beta$-ciklodextrin kopolimer FTIR spektruma

\subsection{SEM}

The surface morphology of beetroot peels, $\beta$-Cyclodextrin, and the modified copolymer synthesized is investigated under scanning electron microscopy. The images are shown in Figs. 2. $a$ to 2.c.

B-Cyclodextrin shows a regular surface with no intruding pores. However, the larger particles are scattered and overlaid with smaller particles. The beetroot peels depict a lump of aggregates with lamellar and non-homogenous surface (see Fig. 2.b). In addition, few crevices are also visible in the larger aggregate of beetroot.

The synthesis of copolymer can be easily followed in SEM images. The modification of $\beta$-Cyclodextrin and beetroot peels is witnessed as formation of continuous layer of $\beta$-Cyclodextrin as base film with beetroot modification on the surface. This modification is also accompanied with formation of new clearly distinct channels with defined pore volume (see Fig. 2.c). This indicates the change in surface morphology of the individual entities of $\beta$-Cyclodextrin and beetroot peels into a modified copolymer. The modification also favours the binding ability of $\beta$-Cyclodextrin with the guest molecules [16]. The development of channels in the modified copolymer is expected to act as adsorbent sites for the incoming pollutants to enhance the host-guest interactions of the inclusion complex [2].

\subsection{XRD}

The structure of the modified copolymer synthesised from $\beta$-Cyclodextrin and beetroot peels is predicted from XRD analysis. The XRD diffractogram (shown in Fig. 3) reveals the amorphous nature of the copolymer. The diffraction pattern with low intensity of 15.660 at $2 \theta$ [11] also indicate grain structure of synthesized material. The halo-diffused pattern for entirely amorphous copolymer of cyclodextrin was also identified by [17].

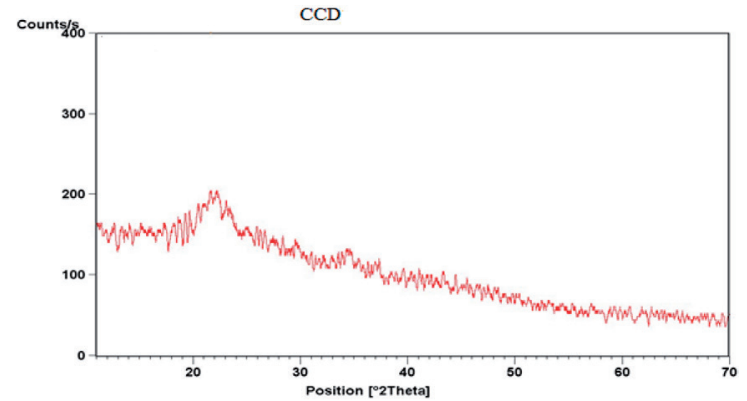

Fig. 3. XRD of synthesized $\beta$-Cyclodextrin modified beetroot peels copolymer 3. ábra A cékla héjjal módosított $\beta$-ciklodextrin kopolimer röntgendiffraktogramja

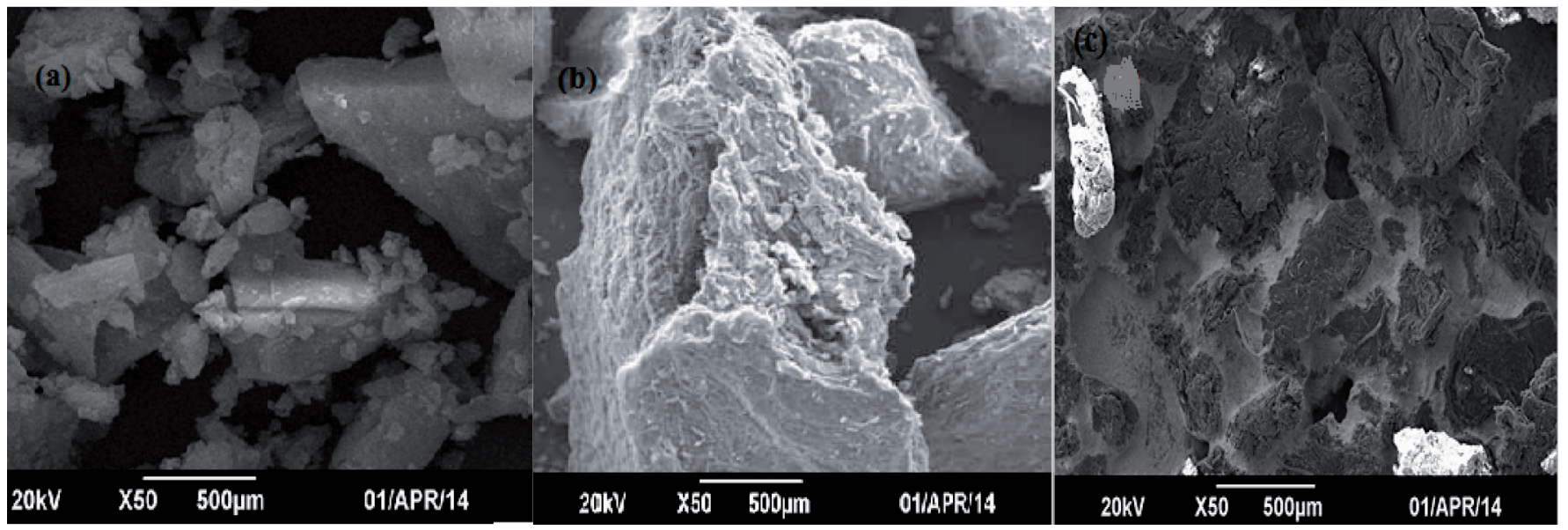

Fig. 2. SEM images of (a) $\beta$-Cyclodextrin (b) Beetroot peels (c) modified copolymer

2. ábra Pásztázó elektronmikroszkópos felvételek (a) $\beta$-ciklodextrin (b) cékla héj (c) módosított kopolimer 


\subsection{Batch adsorption experiment}

A closed batch approach is adopted to investigate the adsorption capacity of synthesized copolymer as an adsorbent for the removal of dyes. The absorbance of Crystal violet and Congo red was recorded on UV-Visible spectrophotometer at $\lambda$ max of $590 \mathrm{~nm}$ and $497 \mathrm{~nm}$, respectively. Batch experiment was applied at variable adsorbent dosages $(1 \mathrm{mg}, 10 \mathrm{mg}, 20 \mathrm{mg})$ and induced dye concentrations $(0.01 \mathrm{mg} / \mathrm{L}, 0.03 \mathrm{mg} / \mathrm{Land}$ $0.05 \mathrm{mg} / \mathrm{L}$ ).

The synthesized modified copolymer is applied as adsorbent for the removal of the selected dyes in a batch mode as a function of time. The results are graphically presented in Figs. 4. $a$ and 4.b. It is observed that the synthesized modified copolymer shows successive removal of Crystal violet and Congo red and continues till dynamic equilibrium [30] is attained in 25-30 minutes of contact. The incremental increase indicates that the process is non-linear and involves more than one step. Each step is operative independent of each other. However, the relatively rapid initial uptake is due availability of more vacant pores. The optimum removal of Congo red (67\%) is relatively more than Crystal violet (59\%). This suggests that the surface of the adsorbent has more susceptibility for the earlier likely due to acidic nature of Congo red showing stronger bonding to extensive $-\mathrm{OH}$ groups available on the surface of $\beta$-Cyclodextrin. Maxima of adsorption is followed by desorption partly due to saturation of sites and repulsive forces between the solute molecules [21] and groups of the synthesized adsorbent. The adsorption mechanism of modified copolymer is proposed to involve film diffusion and intraparticle diffusion simultaneously [24].
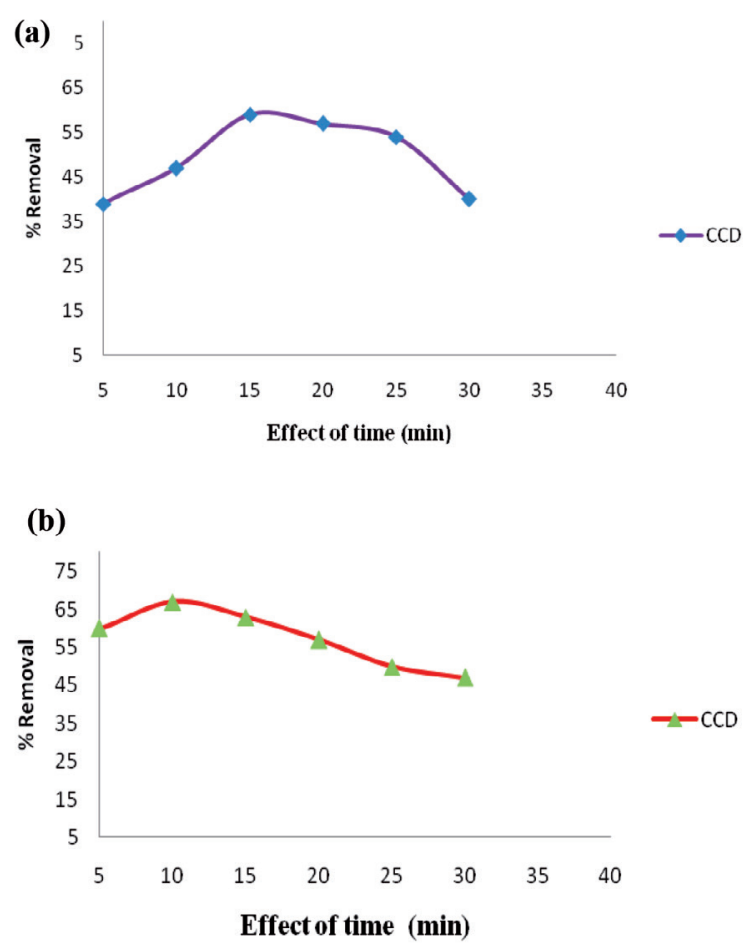

Fig. 4. Removal (in \%age) of (a) Crystal violet (b) Congo red on synthesized copolymer as a function of time

4. ábra Indikátorok átcsapása a szintetizált kopolimerben a hatásidö függvényében (a) kristályibolya, (b) Kongóvörös

\subsection{Effect of dose}

The amount of adsorbent is varied to determine the effect of dose on the removal capacity. In the present investigation, dose of $1 \mathrm{mg} / \mathrm{Kg}, 10 \mathrm{mg} / \mathrm{Kg}$ and $20 \mathrm{mg} / \mathrm{Kg}$ is applied for the removal of dyes. The results are graphically presented in Figs. 5.a and 5.b. It is generally understood that as the dose increases, the adsorption sites are expected to increase and thus the adsorption potential [29]. Elevated increase in adsorption potential commensurate with the increase in adsorbent dose. This is equally good for the removal of both Congo red and Crystal violet. It justifies increasing surface area and availability of more exchange sites on the surface of adsorbents as supported by [18].
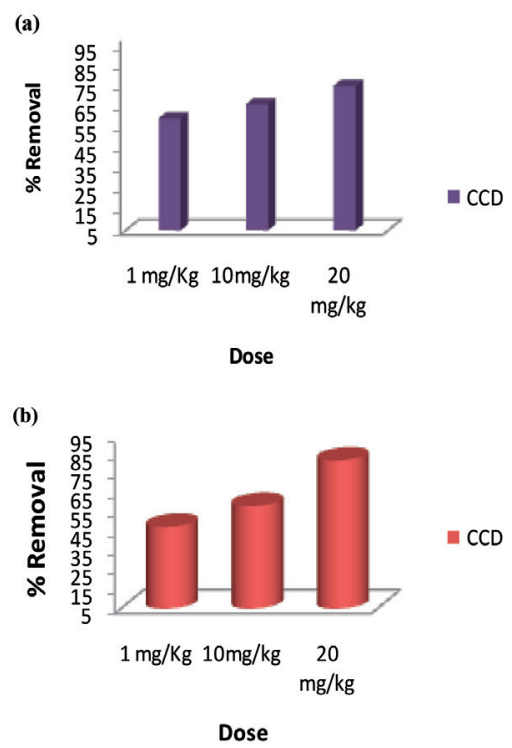

$$
\begin{aligned}
& \text { Fig. 5. Removal (in \%age) of (a) Crystal violet (b) Congo red on synthesized } \\
& \text { copolymer as a function of dose } \\
& \text { 5. ábra Indikátorok átcsapása a szintetizált kopolimerben az adagolás függvényében } \\
& \text { (a) kristályibolya, (b) Kongóvörös }
\end{aligned}
$$

\subsection{Effect of Concentration}

The dye concentration is an important parameter to define the threshold for the uptake on the surface of adsorbent. The synthesized modified copolymer is tested against induced dye concentration of $0.01 \mathrm{mg} / \mathrm{L}, 0.03 \mathrm{mg} / \mathrm{L}$, and $0.05 \mathrm{mg} / \mathrm{L}$. The results are graphically presented in Figs. 6.a and 6.b. A regular increase in removal percentage of Crystal violet [19] is observed upon exposure of higher concentration of dye. More is the induced concentration of dye; more is the uptake of the dye on fixed dose of modified copolymer. The increase in initial concentration is likely to enhance interaction between adsorbent and dye. Similar results are observed by other researchers for dye uptake on adsorbents like activated carbon [27], carbon nanotube [25], oak sawdust [1], rice husk [26] cashew nut shell [14].

The augmented adsorption with increase in induced concentration may be attributed to complete mass transfer between the aqueous and solid phase of the dye molecules [16]. This reflects that the process of adsorption between the exposed concentration and adsorbent dose is continued and the spaces are still available for the uptake of more dye. 
However, relatively less adsorption potential also suggests that removal is a slower and relatively less efficient process for Crystal violet [6].

On the contrary, Congo red shows more (86\%) and faster (10 minutes) adsorption on modified copolymer. Furthermore, a maximum of removal ( $86 \%)$ is found at induced concentration of $0.03 \mathrm{mg} / \mathrm{L}$ defining the optimum.

A decline in adsorption on further increase in concentration (see Fig. 6.b) suggests that the sites are being vacated after attaining saturation of congo red. This may be explained that mono ionic layer is formed at low concentration over the adsorbent surface [15]. The proposed mechanism may conclude that adsorption of Congo red and Crystal violet is governed by physicochemical and physical adsorption, respectively [19].
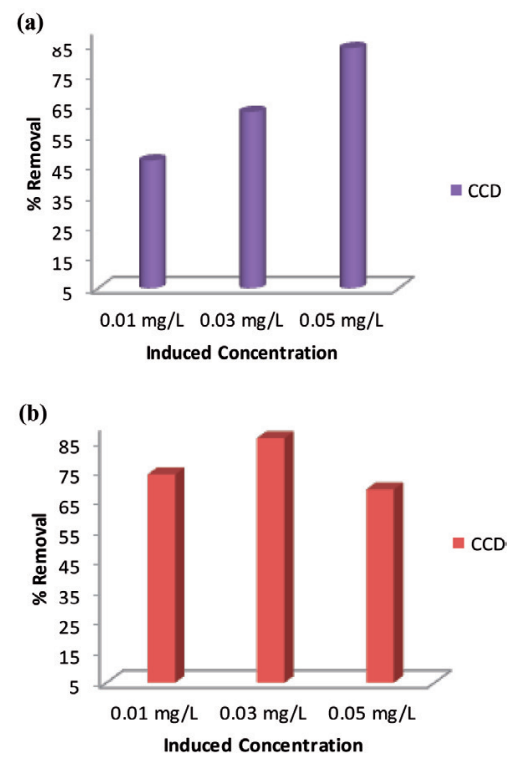

Fig. 6. Removal of dyes (a) Crystal violet (b) Congo red as a function of induced concentration

6. ábra Indikátorok átcsapása a szintetizált kopolimerben a koncentrácio függvényében (a) kristályibolya, (b) Kongóvörös

\section{Conclusions}

The following conclusions can be drawn from the present research work:

The method adopted provides an efficient, easy and an innovative greener approach towards modification of $\beta$-Cyclodextrin with natural source of beetroot peels.

The synthesized copolymer is proven to be a good and efficient adsorbent for the removal of toxic azo dyes (Congo red, Crystal violet) from aqueous environment under varying parameters.

The study provides a good and cheaper alternate to commercial and expensive adsorbents.

It recommends the commercial viability of synthesized modified copolymer for in-situ remediation of industrial pollutants.

\section{References}

[1] Ei-latif, M. M. Abd - Ibrahim, A. M. - Kady, M. F. E. I. (2010): J. Am. Sci Vol. 6 pp. 267-283.

[2] Ansari, R. - Seyghali, B. - Khah, M. A. (2012): Journal Surfact Deterg Vol 15 pp. 557-565. https://doi.org/10.1007/s11743-012-1334-3
[3] Bao, J. Y. - Wen, C. D. (2013): Chinese Journal of Analytical Chemistry Vol. 41 No. 8 pp. 1264-1268. https://doi.org/10.1016/S1872-2040(13)60675-1

[4] Barikani, M. - Mohammadi, M. (2007): Carbohydrate Polymers Vol. 68 pp. 773-780. https://doi.org/10.1016/j.carbpol.2006.08.017

[5] Browski, D. (2001): Advances in Colloid and Interface Science Vol. 93 pp. 135-224.

[6] Crini, G. (2005): Progress in polymer science and thermodynamic study Vol. 30 No. 1 pp. 38-70. https://doi.org/10.1016/S0001-8686(00)00082-8

[7] Da'na, E. - Sayari, A. (2011): Chemical Engineering Journal Vol. 166 No. 1 pp. 445-453.

[8] Dhodapkar, R. - Borde, P. - Nandy, T. (2009): Global Nest Journal Vol. 11 No. 2 pp. 223-234. https://doi.org/10.1016/j.cej.2010.11.016

[9] Fatima, T. - Uzaira, R. (2015): International Journal of Innovation and Scientific Research Vol. 13 No. 2 pp. 485-496.

[10] Gidwani, B. - Vyas, A. (2014): Colloids and Surfaces B: Biointerfaces Vol. 114 pp. 130-137. https://doi.org/10.1016/j.colsurfb.2013.09.035

[11] Jiang, H. - Zujin, A. N. G. - Xiantai, H. O. U. (2012): Chinese Journal of Chemical Engineering Vol. 20 No. 4 pp. 784-792. https://doi.org/10.1016/S1004-9541(11)60249-8

[12] Julinova, M. - Slavik, R. (2012): Journal of Environmental Management Vol. 94 pp. 13-24. https://doi.org/10.1016/j.jenvman.2011.09.006

[13] Khatoon, L. N. - Khan, H. A. - Pathak, V. (2013): International Journal of Innovative Research in Science, Engineering and Technology Vol. 2 No. 11 pp. 2319-8753.

[14] Kumar, S. - Ramalingam, S. - Senthamarai, C. (2010): Desalination, Vol. 261 pp. 52-60. https://doi.org/10.1016/j.desal.2010.05.032

[15] Nidheesh, P. V. - Gandhimathi, R. - Ramesh, S. T. (2012): Turkish Journal of Engineering and Environmental Sciences Vol. 36 No. 3 pp. 249-262. https://doi.org/10.3906/muh-1110-3

[16] Norasiha, H. (2011): PhD Thesis, University of Malaysia Pahang

[17] Parkpain, P. - Sreesai, S. - Delaune, R. D. (2014): Water, Air and Soil Pollution Vol. 122 pp. 163-182. https://doi.org/10.1023/A:1005247427037

[18] Patil, A. K. - Shrivastava, V. S. (2010): International Journal of Chem Tech Research Vol. 2 No. 2 pp. 842-850.

[19] Patil, M. S - Deshmukh, V. - Renukdas, S. (2011): International Journal of Environmental Sciences Vol. 1 No. 6 pp. 0976 - 4402.

[20] Pentyala, N. S. - Rebecchi, M. - Mishra, S. (2011): Environment. Polluiont. Ecological. Human. Health Vol. 23 pp. 249-262.

[21] Priya, R. - Nithya, R. - Anuradha, R. (2014): International Journal of Chem Tech Research Vol. 6 No. 9 pp. 4346-4351.

[22] Rima, J. - Assaker, K. (2013): Inorganic Contaminants from Water Vol. 2 No. 1 pp. 887-895. https://doi.org/10.5539/jfr.v2n1p150

[23] Sambasevam, P. K. - Mohamad, S. - Sarih, M. N. (2013): International Journal Mol. Science Vol. 14 pp. 3671-3682. https://doi.org/10.3390/ijms14023671

[24] Sen, T. K. - Afroze, S. - Ang, H. (2011): Water, Air, \& Soil Pollution Vol. 2 No. 18 pp. 499-515. https://doi.org/10.3390/ijms14023671

[25] Shahryari, Z. - Goharrizi, A. S. - Azadi, M. (2010): Int. J. Water Resour. Environ. Eng Vol. 2 pp. 16-28.

[26] Sharma, P. - Kaur, R. - Baskar, C. (2010): Desalination, Vol. 259 pp. 249257. https://doi.org/10.1016/j.desal.2010.03.044

[27] Sharma, Y. C. (2009): Journal of Chemical \& Engineering Data Vol. 55 pp. 435-439. https://doi.org/10.1021/je900408s

[28] Stalin, T. - Srinivasan, K. - Sivakumar, K. (2014): Journal of Molecular Structure Vol. 106 pp. 239-250. https://doi.org/10.1016/j.molstruc.2013.11.048

[29] Vanitha, T. (2014): International Research Journal of Advanced Zoology, Animal Science and Nutrition (SIRJ-AZASN) Vol. 1 No. 1 pp. 2349 - 4263.

[30] Wanyonyi, C. W. - Onyari, M. J. - Shiundu, M. P. (2014): Energy Procedia Vol. 50 pp. 862 - 869. https://doi.org/10.1016/j.egypro.2014.06.105

Ref::

Tariq, Fatima- Rafique, Uzaira: Design and Application of $\beta$-Cyclodextrinbased Potential Adsorbent for Remediation of Azo Dyes Építőanyag - Journal of Silicate Based and Composite Materials, Vol. 70, No. 3 (2018), 82-85. p https://doi.org/10.14382/epitoanyag-jsbcm.2018.15 